\title{
Bispecific Tau Antibodies with Additional Binding to C1q or Alpha-Synuclein
}

\author{
Wim Hendricus Quint ${ }^{\mathrm{a}}$, Irena Matečko-Burmann ${ }^{\mathrm{b}, \mathrm{c}}$, Irene Schilcher ${ }^{\mathrm{d}}$, Tina Löffler ${ }^{\mathrm{d}}$, \\ Michael Schöll $^{\mathrm{b}, \mathrm{c}, \mathrm{e}}$, Björn Marcus Burmann ${ }^{\mathrm{b}, \mathrm{f}}$ and Thomas Vogels ${ }^{\mathrm{a}, \mathrm{c}, \mathrm{e}, *}$ \\ ${ }^{a}$ Maptimmune BV, The Hague, The Netherlands \\ ${ }^{\mathrm{b}}$ Wallenberg Centre for Molecular and Translational Medicine, University of Gothenburg, Gothenburg, Sweden \\ ${ }^{\mathrm{c}}$ Department of Psychiatry and Neurochemistry, University of Gothenburg, Gothenburg, Sweden \\ ${ }^{\mathrm{d}}$ QPS Austria GmbH, Neuropharmacology, Grambach, Austria \\ ${ }^{\mathrm{e}}$ Department of Neurodegenerative Disease, UCL Queen Square, Institute of Neurology, University College \\ London, London, UK \\ ${ }_{\mathrm{f}}^{\mathrm{f}}$ Department of Chemistry and Molecular Biology, University of Gothenburg, Gothenburg, Sweden
}

Accepted 7 January 2021

\begin{abstract}
.
Background: Alzheimer's disease (AD) and other tauopathies are neurodegenerative disorders characterized by cellular accumulation of aggregated tau protein. Tau pathology within these disorders is accompanied by chronic neuroinflammation, such as activation of the classical complement pathway by complement initiation factor C1q. Additionally, about half of the AD cases present with inclusions composed of aggregated alpha-synuclein called Lewy bodies. Lewy bodies in disorders such as Parkinson's disease and Lewy body dementia also frequently occur together with tau pathology.

Objective: Immunotherapy is currently the most promising treatment strategy for tauopathies. However, the presence of multiple pathological processes within tauopathies makes it desirable to simultaneously target more than one disease pathway. Methods: Herein, we have developed three bispecific antibodies based on published antibody binding region sequences. One bispecific antibody binds to tau plus alpha-synuclein and two bispecific antibodies bind to tau plus C1q.

Results: Affinity of the bispecific antibodies to their targets compared to their monospecific counterparts ranged from nearly identical to one order of magnitude lower. All bispecific antibodies retained binding to aggregated protein in patient-derived brain sections. The bispecific antibodies also retained their ability to inhibit aggregation of recombinant tau, regardless of whether the tau binding sites were in $\mathrm{IgG}$ or $\mathrm{scFv}$ format. Mono- and bispecific antibodies inhibited cellular seeding induced by AD-derived pathological tau with similar efficacy. Finally, both Tau-C1q bispecific antibodies completely inhibited the classical complement pathway.

Conclusion: Bispecific antibodies that bind to multiple pathological targets may therefore present a promising approach to treat tauopathies and other neurodegenerative disorders.
\end{abstract}

Keywords: Alpha-synuclein, Alzheimer's disease, C1q, immunotherapy, synucleinopathies, tau, tauopathies

\section{INTRODUCTION}

Tauopathies are characterized by cellular accumulations of aggregated tau, such as the neurofibrillary tangles (NFTs) in Alzheimer's disease (AD) [1, 2].

*Correspondence to: Thomas Vogels, Maptimmune, Wilde Gagel 30, 2498EP The Hague, The Netherlands. Tel.:+31 647219377 ;

E-mail: t.vogels@maptimmune.com.
About $50 \%$ of the AD cases also contain $\alpha$-synuclein ( $\alpha$ Syn) inclusions called Lewy bodies [3, 4]. When present, Lewy body pathology contributes significantly to the clinical presentation of $\mathrm{AD}$ [5-11]. Likewise, tau pathology is often present in synucleinopathies such as Parkinson's disease (PD) and dementia with Lewy bodies (DLB) [3, 4]. The presence of NFTs is not only strongly correlated to disease progression in tauopathies, but also contributes to 
neurodegeneration as well as clinical symptoms in different synucleinopathies [12-17]. Furthermore, there is increasing evidence indicating a biological interaction between tau and $\alpha$ Syn pathology $[3,18-$ $21]$. The last decade of research has also demonstrated many similarities in the pathological processes induced by tau and $\alpha$ Syn pathology: both proteins can progressively aggregate via templated misfolding (also known as 'seeding'), accumulate into cells as fibrillar $\beta$-sheet rich aggregates, and can spread to other cells, thereby propagating their pathology $[2$, 22].

Tauopathy patients as well as transgenic animals with tau pathology also exhibit chronic neuroinflammation, which plays a key role in neurodegeneration [23]. One pro-inflammatory pathway that is robustly upregulated in response to tau pathology is the classical complement cascade [24-27]. Since complement is also induced by $\mathrm{AD}$-related $\mathrm{A} \beta$ plaque pathology $[28,29]$, it may be of particular importance to $\mathrm{AD}$. The complement-initiating protein $\mathrm{C} 1 \mathrm{q}$ is an extracellular protein that, in the context of neurodegeneration, is critical in synapse phagocytosis by microglia $[24,30]$, activation of neurotoxic A1 astrocytes [31], and neurodegeneration associated with activation of downstream complement components (e.g., C3, C5a) [25, 26, 32].

Immunotherapy is currently the most established approach for treating neurodegenerative disorders associated with protein aggregates (proteinopathies), such as tauopathies and synucleinopathies [33]. The dominating functional mechanism of these immunotherapies is antibody-mediated neutralization of misfolded and aggregated proteins in the extracellular space [34]. This process inhibits seeded aggregation in healthy cells, thereby potentially reducing the propagation of the disease progression [35]. Neutralizing antibodies against extracellular pro-inflammatory proteins have also been explored as a potential treatment strategy for proteinopathies [36, 37]. A neutralizing anti-C1q antibody inhibiting the classical complement pathway was shown to rescue both $A \beta$ and tau pathology-induced synapse phagocytosis by microglia $[24,30]$.

There is growing consensus that the ultimately effective treatment for proteinopathies will consist of a combination treatment [38]. However, regulatory hurdles make it difficult to test combination treatments without showing efficacy of the individual drugs in a first stage. Furthermore, employing two drugs simultaneously complicates dose optimization in clinical trials. In the case of immunotherapy, combining two or more monoclonal antibodies may result in unsustainable treatment costs. Additionally, brain uptake of $\mathrm{IgG}$ is limited, and two monoclonal antibodies may compete for the same pathways, which may lead to lower uptake of both antibodies. This is particularly the case for the anticipated novel generation of antibodies, which bind to saturable proteins (e.g., transferrin) on the blood-brain barrier to promote their uptake in the brain parenchyma [39, 40].

The goal of the present study was to explore a novel approach: bispecific antibodies that simultaneously bind to two proteins involved in the pathological process of $\mathrm{AD}$ and other tauopathies. The use of bispecific antibodies that bind to two disease-related targets has increased in the past years in other fields (e.g., oncology), but - to the best of our knowledgethis has not yet been explored for the treatment of neurodegeneration [41]. In the present study we have developed bispecific antibodies based on published immunoglobulin $\mathrm{G}$ ( $\mathrm{IgG}$ ) complementaritydetermining regions (CDRs) binding to tau plus $\alpha$ Syn as well as tau plus C1q. We have decided to focus on two proteinopathy targets for which the mechanism of action of immunotherapy is supposed to be similar, as both anti-tau and anti- $\alpha$ Syn antibodies are thought to prevent their propagation through the brain by blocking cellular uptake [42]. This contrasts with targeting $A \beta$ with immunotherapy, which is supposed to remove deposited plaques from the brain [43]. In addition, we combined tau with $\mathrm{C} 1 \mathrm{q}$ to explore the possibility of targeting one proteinopathy and one neuroinflammation-related target. We show that the bispecific antibodies retained their target-binding and therapeutic effects in functional assays.

\section{METHODS}

\section{Human brain tissue}

The brain samples were obtained from The Netherlands Brain Bank (NBB), Netherlands Institute for Neuroscience, Amsterdam (open access: www. brainbank.nl). All material has been collected from donors for or from whom a written informed consent for a brain autopsy and the use of the material and clinical information for research purposes had been obtained by the NBB.

Paraffin-embedded middle frontal gyrus of a 68year-old female patient with the Lewy body variant of AD (amyloid C, NFTs Braak VI, Lewy bodies Braak 6, APOE $\varepsilon 4 / 3$ ) and the same region from a 
non-demented 69-year-old female (amyloid -, NFTs Braak I, Lewy bodies Braak 0, APOE $\varepsilon 3 / 3$ ) were used for histological analysis. The middle frontal gyrus in this patient was previously characterized by the brain bank and shown to be heavily affected by $\mathrm{A} \beta$ plaques, NFTs, and Lewy body pathology. The postmortem delay was $3: 30 \mathrm{~h}$ for the patient tissue and $6: 15 \mathrm{~h}$ for the non-demented control tissue.

For the cellular seeding assay, a pool of frozen, non-fixed material was used. This consisted of angular gyrus of two male AD patients (ages 63 and 64 years old; 6; both $A P O E \varepsilon 3 / 3$ ) and superior parietal gyrus of four female AD patients (ages between 77 and 92 years old; $A P O E$ allele $\varepsilon 3 / 3, \varepsilon 3 / 4$, and $\varepsilon 4 / 4$ ). All samples were Braak stage VI for tau pathology and had a postmortem delay ranging from 3:00 to $4: 45 \mathrm{~h}$.

\section{Production of bispecific antibodies}

Production of bispecific antibodies was performed at Absolute Antibody (UK). The produced bispecific antibodies consist of a mouse IgG1 molecule with two scFv molecules fused at the carboxy-terminus of the heavy chain. Variable domains from publicly available DNA sequences were designed and optimized for expression in mammalian cells (HEK 293) prior to being synthesized. The tau binding regions from mono- and bispecific variants of antibody A were derived from clone hu37D3-H9.v28 (US201 90367592A1), which bind the distal N-terminus of tau (requiring tau residues Y18A and L20A). The tau binding regions from mono- and bispecific variants of antibody $\mathrm{B}$ were derived from clone $\mathrm{AB} 1$ (WO2017005734A1), which binds to the central region of tau (amino acids 235-246) [44]. The $\alpha$ Syn binding regions were derived from clone M9E4 (US 20200024336A1), which recognizes the C-terminus (amino acids 118-126) [45]. The C1q binding regions were derived from clone M1 (US10590190B2), which binds a conformational epitope on C1q [30]. The sequences were subsequently cloned into Absolute Antibody cloning and expression vectors for mouse $\mathrm{IgG} 1$ and $\mathrm{scFv}$. The $\mathrm{Clq}$ binding antibodies had an additional D265A mutation in the mouse IgG1 backbone to eliminate potential C1q binding in the Fc domain [46]. HEK293 cells were passaged to the optimum stage for transient transfection. Cells were transiently transfected with expression vectors and cultured for a further 6-14 days. An appropriate volume of cells was transfected with the aim to obtain $1-5 \mathrm{mg}$ of purified antibody. Cultures were harvested and a one-step purification was performed by affinity chromatography. The antibodies were analyzed for purity by SDS-PAGE and the concentration was determined by UV spectroscopy. This format of the resulting bispecific antibodies is commonly referred to as IgG-scFv, IgG-scFv (HC), or BiS3.

\section{Enzyme-linked immunosorbent assay (ELISA)}

ELISA was performed at Absolute Antibody (UK). Maxisorb micro microplates were coated with $5 \mu \mathrm{g} / \mathrm{ml}$ of antigen in PBS for $1 \mathrm{~h}$. Solutions were removed, and plates were blocked overnight at $4{ }^{\circ} \mathrm{C}$ in $1 \%$ casein solution. Solutions were removed and plates were washed once with PBS with $0.02 \%$ Tween-20. Antibody samples were added in duplicates and incubated for $1 \mathrm{~h}$ with shaking at room temperature. Plates were washed 4 times with PBS supplemented with $0.02 \%$ Tween-20. Goat anti-mouse HRP conjugated secondary antibody (1:4000 dilution) was added and incubated for 1 hour with shaking at room temperature. Plates were washed 4 times with PBS with Tween-20 followed by washing twice with water. Detection was performed by incubation with the TMB substrate for $10 \mathrm{~min}$, followed by $0.1 \mathrm{M} \mathrm{HCl}$. Absorbance was read out at $450 \mathrm{~nm}$.

\section{Purification of recombinant proteins}

For the expression and purification of recombinant Tau40 (2N4R), E. coli BL21 ( $\lambda$ DE3) Star ${ }^{\mathrm{TM}}$ (Novagen) cells were transfected with a modified $p E T 28 b$ plasmid harboring full length Tau40 protein with an amino-terminal His-SUMO Tag (purchased $E$. coli codon optimized from GeneScript). Transformed cells were spread on LB-Agar plates containing Kanamycin $(40 \mu \mathrm{g} / \mathrm{ml})$ (Sigma Aldrich) and grown overnight at $37^{\circ} \mathrm{C}$. For protein expression and purification, the cells were pre-cultured overnight in $2 \times$ M9 medium [47] (supplemented with Kanamycin $(40 \mu \mathrm{g} / \mathrm{ml})$ at $30^{\circ} \mathrm{C}$. The main culture was inoculated with the precultured medium to an $\mathrm{OD}_{600} \approx 0.1$ and grown at $37^{\circ} \mathrm{C}$ until a cell density of $\mathrm{OD}_{600} \approx 0.8$ was reached at $37^{\circ} \mathrm{C}$. Protein expression was induced by the addition of $1 \mathrm{mM}$ isopropyl $\beta$-D-thiogalactoside (IPTG) (Thermo Scientific) for $16 \mathrm{~h}$ at $22^{\circ} \mathrm{C}$. Cells were harvested by centrifugation at $5.000 \times \mathrm{g}$ at $4^{\circ} \mathrm{C}$ for $20 \mathrm{~min}$. The resulting cell pellet was washed once with ice cold PBS/EDTA buffer $(0.137 \mathrm{M} \mathrm{NaCl}$, $0.0027 \mathrm{M}, 0.01 \mathrm{M} \mathrm{Na} \mathrm{HPO}_{4}, 0.0018 \mathrm{M} \mathrm{KH}_{2} \mathrm{PO}_{4}$, $2 \mathrm{mM}$ EDTA), subsequently resuspended in $80 \mathrm{ml}$ ice cold lysis/binding $(0.025 \mathrm{M} \mathrm{NaPi}$ pH7.8, $0.5 \mathrm{M} \mathrm{NaCl})$ 
buffer and lysed by four passes through an Emulsiflex (Avestin).

The cleared cell lysate was centrifuged at $22000 \times$ $\mathrm{g}$ for $1 \mathrm{~h}$ at $4^{\circ} \mathrm{C}$. The supernatant was directly applied to a HisTrap HP column (GE Healthcare), equilibrated with binding buffer, washed with 5 column volumes of the same buffer supplemented with $25 \mathrm{mM}$ imidazole. Tau protein was eluted with a $150 \mathrm{mM}$ imidazole step. Fractions containing Tau40 were pooled and dialyzed overnight, against $5 \mathrm{~L}$ human SenP1 cleavage buffer ( $25 \mathrm{mM}$ TrisHCl, 150 $\mathrm{mM} \mathrm{NaCl}, 1 \mathrm{mM}$ DTT, $\mathrm{pH}$ 7.4). After dialysis Sen P1 protease (Addgene plasmid \#16356) [48] was added and the enzymatic cleavage was performed for $4 \mathrm{~h}$ at room temperature. Separation of the HisSUMO-Tag and Tau40 was done by a second HisTrap HP column step and fractions containing cleaved Tau40 in the flow-through were collected, concentrated, and subsequently purified by gel filtration using a HiLoad 10/60 200 pg column (GE Healthcare) pre-equilibrated with PBS buffer supplemented with $2 \mathrm{mM}$ EDTA. Pure tau fractions were concentrated to about $500 \mu \mathrm{M}$, flash frozen in liquid nitrogen, and stored at $-80^{\circ} \mathrm{C}$ till usage.

Human $\alpha$ Syn was expressed from plasmid pRK 172 (a kind gift of M. Goedert) [49] in E. coli BL21 ( $\lambda$ DE3) Star $^{\mathrm{TM}}$ (Novagen) cells as described before [50-52]. Briefly, $\alpha$ Syn was purified by a nondenaturing protocol by anion-exchange chromatography followed by a size-exclusion chromatography step using a Superdex75 Increase column (GE Healthcare). The $\alpha$ Syn containing fractions were concentrated to about $500 \mu \mathrm{M}$ and stored at $-80^{\circ} \mathrm{C}$.

\section{Bio-layer interferometry (BLI)}

BLI experiments were performed on an OctetR ED96 system (Fortébio) at $30^{\circ} \mathrm{C}$. Recombinant Tau 40, $\alpha$ Syn, and C1q (Abcam; ab96363) were biotinylated using the EZ-Link NHS-PEG4 Biotinylation Kit (Thermo Fisher Scientific) according to the manufacturer's instructions. Briefly, a biotin aliquot was freshly resolved in $\mathrm{H}_{2} \mathrm{O}$, directly added to the protein solution to a final molar ratio of 1:1 in PBS buffer and the solution was gently mixed for $30 \mathrm{~min}$ at room temperature. Unreacted biotin was removed with Zeba Spin Desalting Columns (7 MWCO, Thermo Fisher Scientific). Biotin-labelled proteins were immobilized on the streptavidin (SA) biosensors (Fortébio) and the biosensors were subsequently blocked with EZ-Link Biocytin (Thermo Fisher Scientific). The different antibodies used were diluted and applied in a dose-dependent manner to the biosensors immobilized with the respective proteins. Experiments were performed in PBS buffer $\mathrm{pH} 7.4$ supplemented with $1 \%$ Bovine serum albumin (BSA) (Sigma-Aldrich) and $0.02 \%$ Tween (Fluka) to avoid non-specific interactions. Parallel experiments were performed for reference sensors with no antibodies bound and the signals were used for baseline subtraction during the subsequent data analysis. The association and dissociation periods were set to $300 \mathrm{~s}$ and $500 \mathrm{~s}$, respectively. Data measurements and analysis were performed by using the Data acquisition 10.0 and the Data analysis HT 10.0 (Fortébio) software, respectively.

\section{Immunofluorescence}

Immunofluorescent histological staining was based on a modified version of a previously published protocol [53]. All steps were performed at room temperature unless mentioned otherwise. Paraffinembedded sections $(8 \mu \mathrm{m})$ were deparaffinized and washed in PBS. Heat antigen retrieval was performed by immersing the sections in sodium citrate buffer ( $10 \mathrm{mM}$ Sodium citrate, $0.05 \%$ Tween 20 , pH 6.0) and boiling in a microwave for $10 \mathrm{~min}$. The sections were then left to cool down at room temperature and subsequently incubated for $1 \mathrm{~min}$ in TrueBlack lipofuscin autofluorescence quencher (Biotium, USA) diluted 1:20 in 70\% ethanol. After washing, sections were blocked for $1 \mathrm{~h}$ in horse serum and incubated in mono- and bispecific antibodies or commercial primary antibodies diluted in PBS overnight at $4^{\circ} \mathrm{C}$. The following dilutions were used: experimental antibodies 1:2000 (from $1 \mathrm{mg} / \mathrm{ml}$ stock), rabbit anti-Tau pS214 1:500 (ab170892, Abcam, UK), rabbit anti$\alpha$ Syn 1:1000 (ab51253, Abcam, UK). The second day, sections were thoroughly washed and incubated for $1 \mathrm{~h}$ in secondary antibodies anti-mouse IgG-Cy2, and anti-rabbit IgG-Cy3 (Thermo Fisher Scientific), both dissolved 1:1000 in PBS containing $10 \mu \mathrm{g} / \mathrm{ml}$ Methoxy-X04 (Tocris Bioscience). After thoroughly washing, slides were coverslipped using anti-fade ProLong ${ }^{\mathrm{TM}}$ Gold Antifade Mountant (Thermo Fisher). Slides were imaged on a Zeiss LSM 700 confocal microscope.

\section{CH50-assay to measure classical complement}

Human serum (Haemoscan, The Netherlands) was diluted $1 / 28$ in dilution buffer and mixed with a previously reported complement-neutralizing dose of 
the C1q antibody: $1 \mu \mathrm{g}$ per test for the monospecific antibodies and $1.25 \mu \mathrm{g}$ for bispecific antibodies to have equal numbers of antibody molecules under all conditions [30]. The antibody:serum mixture was pre-incubated for $1 \mathrm{~h}$ at $4^{\circ} \mathrm{C}$, then mixed with bovine erythrocytes at $37^{\circ} \mathrm{C}$ according to the manufacturer's instructions (Haemoscan, The Netherlands). Stop solution was applied after $30 \mathrm{~min}$, samples were centrifuged for $10 \mathrm{~min}$ at $400 \times \mathrm{g}$ and subsequently measured at $\mathrm{OD}_{415}$ to determine the amount of cell lysis, according to the manufacturer's instructions (Haemoscan, The Netherlands). IgG containing samples were measured in duplicates and data was pooled from 5 independently prepared experiments. Dilution buffer without serum was used as a negative control and serum without experimental antibodies was used as a positive control and the resulting $\mathrm{OD}_{415}$ values were averaged to determine $100 \%$ hemolysis.

\section{Cell-free tau aggregation assay}

Recombinant Tau441 (2N4R) P301L (Analytik Jena, T-1014-1) at $1 \mu \mathrm{M}$ final concentration, was incubated with $30 \mu \mathrm{M}$ sodium octadecylsulfate (ODS) and $1 \mu \mathrm{M}$ heparin in reagent buffer $(20 \mu \mathrm{M}$ Thioflavin T, $5 \mathrm{mM}$ 1,4-dithioerythreitol, $100 \mathrm{mM}$ $\mathrm{NaCl}, 10 \mathrm{mM}$ HEPES $\mathrm{pH} 7.4$ ) for $15 \mathrm{~h}$ at $37^{\circ} \mathrm{C}$ in black no-binding 96 well plates. IgG and $\mathrm{IgG}-\mathrm{scFv}$ were used in the same concentration as recombinant tau $(1 \mu \mathrm{M})$. Compounds were incubated with the before mentioned tau-Heparin-ODS-Buffer solution. Six technical replicates were performed. Immediately after preparation a baseline measurement was carried out and following 4 and $15 \mathrm{~h}$ of incubation at $37^{\circ} \mathrm{C}$, fluorescence was again detected by using $450 \mathrm{~nm}$ excitation and $485 \mathrm{~nm}$ emission.

\section{Extraction of sarkosyl insoluble tau}

The preparation of sarkosyl insoluble brain fraction was performed as described previously [54]. AD brain tissue was homogenized in 3 volumes $(\mathrm{v} / \mathrm{w})$ of cold $\mathrm{H}$ buffer (10 mM Tris, $1 \mathrm{mM}$ EGTA, $0.8 \mathrm{M}$ $\mathrm{NaCl}, 10 \%$ sucrose, $\mathrm{pH} 7.4$, containing 1 mM PMSF) with protease inhibitor (EMD Millipore, 539131). After 20 min incubation on ice the homogenate was spun at $27.200 \times \mathrm{g}$ for $20 \mathrm{~min}$ at $4^{\circ} \mathrm{C}$. Supernatants were supplemented with $1 \%$ sarkosyl and $1 \% 2$ mercaptoethanol final concentration and incubated for $1 \mathrm{~h}$ at $37^{\circ} \mathrm{C}$ on orbital shaker. The samples were then centrifuged at $150,000 \times \mathrm{g}$ for $35 \mathrm{~min}$ at room temperature. The pellet was resuspended in TBS
(10 $\mathrm{mM}$ Tris, $154 \mathrm{mM} \mathrm{NaCl})$ and the insoluble fraction was used as described below.

Capillary electrophoresis-based immunoassay

Automated separation and immunostaining of tau was carried out using a capillary-based immunoassay, $\mathrm{WES}^{\mathrm{TM}}$ (proteinsimple ${ }^{\circledR}$ ). Insoluble sarkosyl extraction samples $(0.2 \mathrm{mg} / \mathrm{mL})$ before and after sonication for $2 \mathrm{~min}$ were applied to a 25-capillary cartridge with a 2 to $440 \mathrm{kDa}$ matrix, according to the manufacturer's protocol. After samples and antibody (Tau-13, BioLegend Inc.) have been pipetted into the pre-filled assay plate purchased from the manufacturer, sample loading, separation, immunoprobing, washing, and detection were performed automatically by $\mathrm{WES}^{\mathrm{TM}}$ Western system. Quantitative data analysis was performed with Compass for SW software (Bio-Techne). The areas under the curve were determined for the subsequent analysis.

\section{Cellular seeding assays with AD-derived tau}

SH-SY5Y-hTau441 P301L cells were kept in culture medium (DMEM medium, 10\% FCS, 1\% NE AA, $1 \%$ L-Glutamine, $100 \mu \mathrm{g} / \mathrm{ml}$ Gentamycin, 300 $\mu \mathrm{g} / \mathrm{ml}$ Geneticin G-418) for $\sim 2$ days until $80-90 \%$ confluency was reached. Next, cells were differentiated in culture medium supplemented with $10 \mu \mathrm{M}$ retinoic acid for 5 days changing medium every 2 to 3 days. Differentiated SH-SY5Y-hTau441 P301L cells were incubated with sarkosyl extracts from brain in combination with two different concentrations of the antibodies. Therefore, $2.5 \mu \mathrm{g}$ total protein of brain extracts were mixed with $300 \mathrm{nM}$ or $30 \mathrm{nM}$ of the antibodies in Opti-MEM and incubated overnight at $4{ }^{\circ} \mathrm{C}$. On the same day, SH-SY5Y-hTau441 P301L cells were seeded in culture medium on 96 -well plates at a cell density of $5 \times 10^{4}$ cells/well. On the next day, the tau-antibody mixtures were incubated for $10 \mathrm{~min}$ with Lipofectamine 2000 (Invitrogen) in Opti-MEM, followed by adding these mixtures to the cells and incubation for $48 \mathrm{~h}$ at $37^{\circ} \mathrm{C}$. Two days after tau treatment, cells were harvested. To this end, cells were washed once with cold PBS and harvested in $50 \mu \mathrm{L}$ FRET lysis buffer (Cisbio) per well and analyzed according to the manufacturer's protocol.

Briefly, samples were diluted 1:2 in lysis buffer and the Anti-human TAU-d2 conjugate as well as the Anti-human $\mathrm{Tau}_{-} \mathrm{Tb}^{3+}$-Cryptate conjugate were diluted 1:50 in diluent solution and premixed. Thereafter, $16 \mu \mathrm{L}$ of the lysates and $4 \mu \mathrm{L}$ premixed conjugates 
were applied to a white 396 well plate and incubated approximately $20 \mathrm{~h}$ at RT on a shaker. Fluorescence emission at two different wavelengths $(665 \mathrm{~nm}$ and $620 \mathrm{~nm}$ ) was performed on a multilabel plate counter (Victor 3V, PerkinElmer). The signal ratio was calculated using the following formula: (Signal $665 \mathrm{~nm} /$ Signal $620 \mathrm{~nm}) \times 10^{4}$.

\section{Statistical analyses}

Statistical analyses and visualization of results was performed in Prism 8 (Graphpad Software, San Diego, CA, USA). Experimental antibodies were compared to vehicle control and each other using a Welch test with correction for multiple comparisons using the Benjamini-Hochberg procedure to keep the false discovery rate below 0.05 (cell free tau aggregation assay; $\mathrm{CH} 50$ assay). This test assumes normally distributed data, but no equal variances between different conditions. For the cellular tau seeding assay, we used the non-parametric Kruskal-Wallis test with Dunn's multiple comparisons test, which does not assume normally distributed data. The threshold of corrected $p$-values in our analysis is 0.05 . Individual data are presented in the graphs along with means and 95\% confidence intervals, unless stated otherwise in the figure legends. Comparisons between monospecific antibodies and their bispecific counterparts were indicated in the graphs with an asterisk if the corrected $p$-value was below the threshold and denoted as no difference (n.d.) when the corrected $p$-value did not cross the threshold.

\section{RESULTS}

Bispecific tau antibodies with additional binding to $\alpha$ Syn and $\mathrm{Clq}$

To validate a novel approach to immunotherapy for tauopathies, we have developed and characterized three bispecific antibodies (Table 1). Antibody A binds to tau plus $\alpha$ Syn, with two tau bindings sites attached as $s c F v$ to the anti- $\alpha$ Syn $\operatorname{IgG}$ (Fig. 1A, Table 1). Antibody B-I is an anti-tau IgG fused to two C1q-binding scFvs (Fig. 1B, Table 1). Antibody $\mathrm{B}-\mathrm{II}$ has the same binding regions as antibody B-II, except that this antibody is an anti-C1q IgG fused to two tau-binding scFvs (Fig. 1C, Table 1). Antibody A allowed us to study immunotherapy binding to two proteinopathy-related targets. Antibody B-I and B-II allowed us to study immunotherapy to tau an inflammation-related target. Furthermore, since antibodies B-I and B-II were identical except for their formats, this also allowed us to compare the influence of the bispecific antibody format on functionality. Antibodies were compared to their monospecific counterparts. Successful production of bispecific antibodies was confirmed by SDS-Page. All three blots looked similar with a single band at $\sim 198 \mathrm{kDa}$ under non-denaturing conditions (Fig. 1D-F). This is consistent with an $\operatorname{IgG}$ molecule having a molecular weight of $\sim 150 \mathrm{kDa}$ plus two scFv molecules with a MW of $\sim 25 \mathrm{kDa}$ each.

\section{Confirmation of target-binding and binding kinetics}

To confirm that the bispecific antibodies retained binding to their targets, we tested them with ELISA. Antibody A efficiently recognized both tau and $\alpha$ Syn (Fig. 1G, J). Both antibody B-I and antibody B-II recognized tau and $\mathrm{Clq}$ (Fig. 1H-L). We then used Octet BLI to determine the binding affinities of the bispecific antibodies, which are summarized in Table 1. Monospecific antibody $\mathrm{A}_{\text {mono-tau }}$ and bispecific antibody A bound with similar affinity to tau $\left(K_{\mathrm{D}}\right.$ values of $35 \mathrm{nM}$ and $50 \mathrm{nM}$, respectively) (Table 1, Fig. 2A). Similarly, monospecific antibody $\mathrm{A}_{\text {mono- } \alpha \text { Syn }}$ and bispecific antibody A bound with similar affinity to $\alpha \operatorname{Syn}\left(K_{\mathrm{D}}\right.$ values of $8.4 \mathrm{nM}$ and $2.3 \mathrm{nM}$, respectively) (Table 1, Fig. 2B). However, monospecific antibody $\mathrm{B}_{\text {mono-tau }}$ had an approximately 10-fold higher affinity compared to both bispecific antibodies B-I and B-II ( $K_{\mathrm{D}}$ value of $35 \mathrm{nM}$ compared to $430 \mathrm{nM}$ and $530 \mathrm{nM}$, respectively) (Table 1, Fig. 2C, E). Antibody $\mathrm{B}_{\text {mono-C1q }}$ also had an $\sim 10$-fold higher affinity to $\mathrm{C} 1 \mathrm{q}$ compared to the bispecific antibody B-I ( $K_{\mathrm{D}}$ value of $20 \mathrm{nM}$ compared to $240 \mathrm{nM}$ ) (Table 1, Fig. 2D).

\section{Binding to neuropathology in patients}

To determine if the bispecific antibodies were able to recognize NFTs and Lewy bodies, we used them as primary antibodies to stain human brain sections of an AD patient with Lewy bodies. Sections were colabelled with Methoxy-X04, a Congo Red-derivative recognizing $\beta$-sheet-rich structures like amyloid plaques, NFTs, and Lewy bodies [55]. When tau binding sites were examined, sections were additionally labelled with an antibody that recognizes tau phosphorylated at the AD-related site serine 214 (pS 214). When $\alpha$ Syn binding sites were examined, sections were additionally labelled with an antibody which recognizes $\alpha$ Syn phosphorylated at the 
Table 1

Antibody binding characteristics

\begin{tabular}{lcccrr}
\hline IgG ID & Target & Protein & $K_{\mathrm{D}}(\mathrm{nM})$ & $\mathrm{R}^{2}$ & $\chi^{2}$ \\
\hline Antibody A Anono-tau & Tau & Tau & $35 \pm 5$ & 0.9851 & 0.0206 \\
Antibody A & $\alpha$ mono- $\alpha$ Syn & $\alpha$ Syn & $8.4 \pm 2.5$ & 0.8319 & 0.2273 \\
Antibody A (bispecific) & $\alpha$ Syn/tau & Tau & $50 \pm 4.0$ & 0.9934 & 0.0743 \\
Antibody A (bispecific) & $\alpha$ Syn/tau & $\alpha$ Syn & $2.3 \pm 0.67$ & 0.7288 & 0.0373 \\
Antibody B Bono-tau & Tau & Tau & $35 \pm 4.4$ & 0.9792 & 0.0696 \\
Antibody B Bono-Clq & $\mathrm{C} 1 \mathrm{q}$ & $\mathrm{C} 1 \mathrm{q}$ & $20 \pm 3.8$ & 0.9365 & 0.0515 \\
Antibody B-I (bispecific) & Tau/C1q & Tau & $430 \pm 100$ & 0.9934 & 0.0246 \\
Antibody B-I (bispecific) & Tau/C1q & $\mathrm{C} 1 \mathrm{q}$ & $24 \pm 2.8$ & 0.9939 & 0.0098 \\
Antibody B-II (bispecific) & $\mathrm{C} 1 \mathrm{q} / \mathrm{tau}$ & Tau & $530 \pm 130$ & 0.9886 & 0.0247 \\
Antibody B-II (bispecific) & $\mathrm{C} 1 \mathrm{q} / \mathrm{tau}$ & $\mathrm{C} 1 \mathrm{q}$ & $280 \pm 110$ & 0.9231 & 0.0251 \\
\hline
\end{tabular}
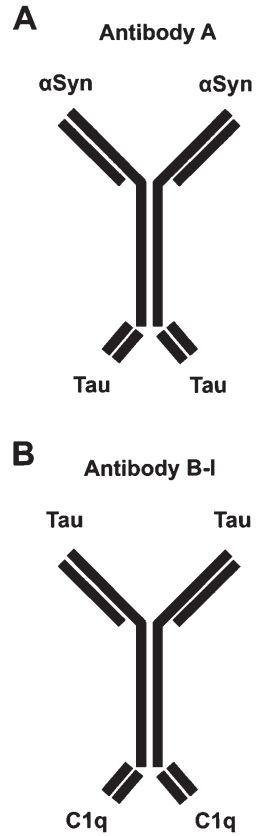

C

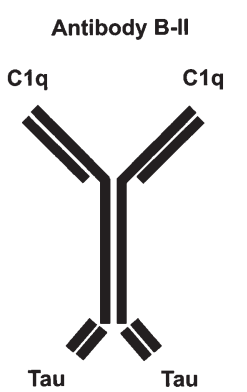

D

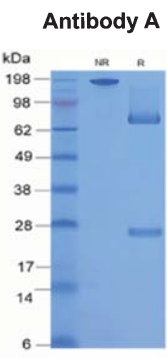

E

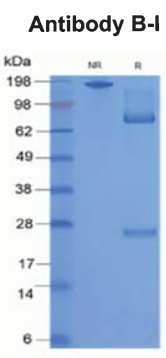

$\mathbf{F}$

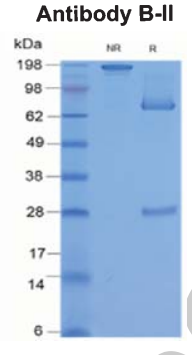

G

Antibody A binding to tau (ELISA)

J

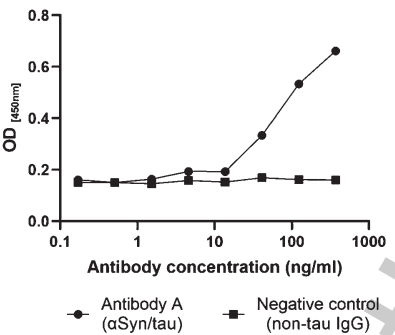

H

Antibody B-I binding to tau (ELISA)

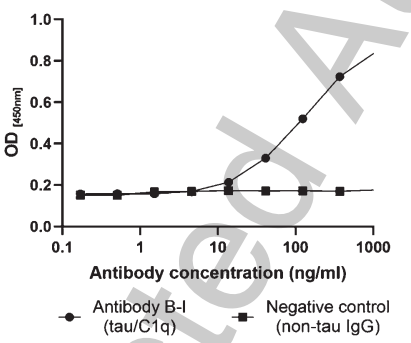

|

Antibody B-II binding to tau (ELISA)

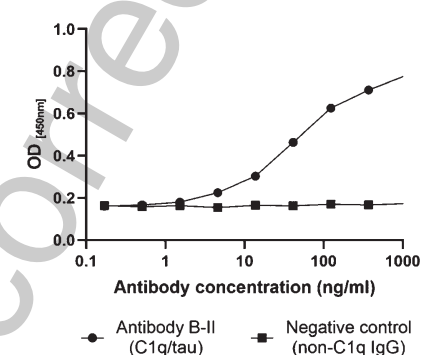

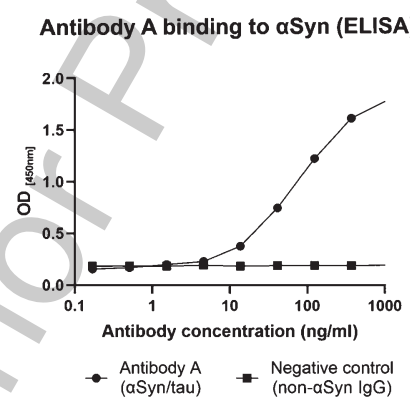

K

Antibody B-I binding to C1q (ELISA)

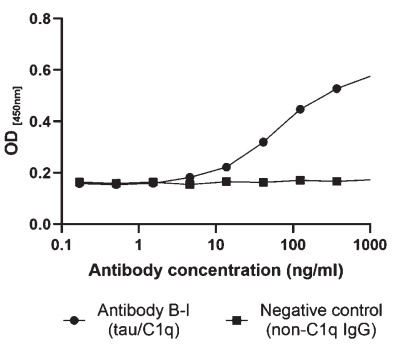

L

Antibody B-II binding to C1q (ELISA)

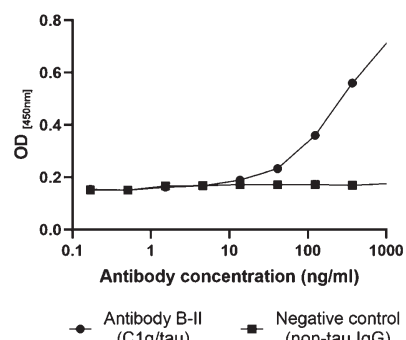

Fig. 1. Antibody characteristics. A) Antibody A is an anti- $\alpha$ Syn IgG with two additional tau-binding scFv domains fused to the Fc domain. B) Antibody B-I is anti-tau IgG with two additional C1q-binding scFv domains fused to the Fc domain. C) Antibody B-II is anti-C1q IgG with two additional tau-binding $\mathrm{scFv}$ domains fused to the Fc domain. D) SDS-PAGE showing the molecular weight of Antibody A under non-reducing conditions in the middle lane and under reducing conditions in the right lane. E) SDS-PAGE showing the molecular weight of Antibody B-I under non-reducing conditions in the middle lane and under reducing conditions in the right lane. F) SDS-PAGE showing the molecular weight of Antibody B-II under non-reducing conditions in the middle lane and under reducing conditions in the right lane. G) ELISA showing binding of Antibody A to recombinant tau. H) ELISA showing binding of Antibody B-I to recombinant tau. I) ELISA showing binding of Antibody B-II to recombinant tau. J) ELISA showing binding of Antibody A to recombinant $\alpha$ Syn. K) ELISA showing binding of Antibody B-I to recombinant C1q. L) ELISA showing binding of Antibody B-II to recombinant C1q. 

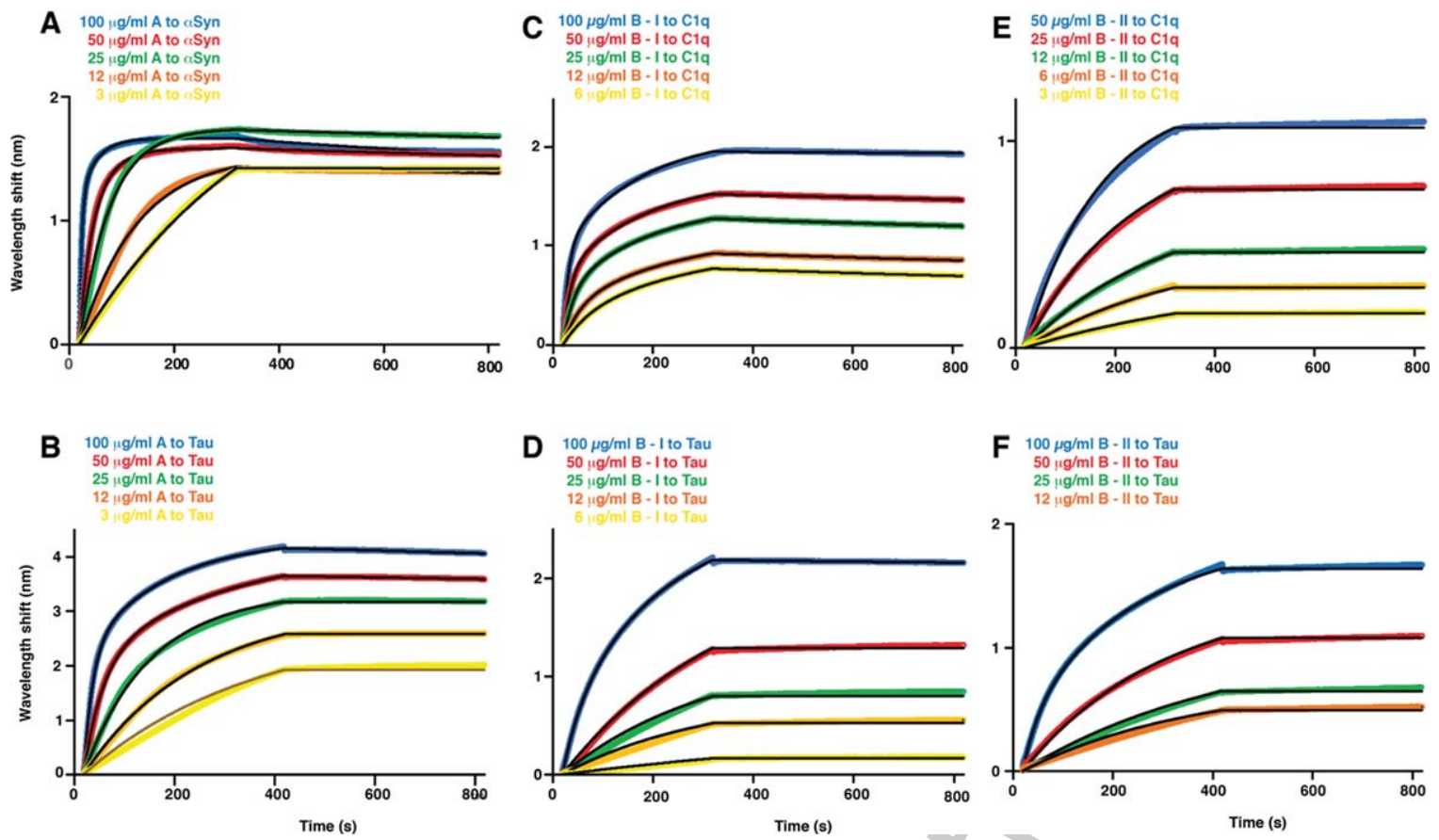

Fig. 2. Sensograms of different bispecific antibodies binding to respective antigens using streptavidin (SA) sensors on an Octet Red96. Tau40, C1q, and $\alpha$ Syn were biotinylated and subsequently immobilized to the sensor. Antibodies were applied in a dose-dependent manner as indicated. A) Antibody A to $\alpha$ Syn. B) Antibody A to Tau40. C) Antibody B-I to C1q. D) Antibody B-I to Tau40. E) Antibody B-II to C1q. F) Antibody B-II to Tau40.

synucleinopathy-related site serine 129 (pS129). Triple-positive structures with typical NFT or Lewy body morphology were therefore interpreted as specific binding. We examined paraffin embedded middle frontal gyrus sections of an AD patient with Lewy bodies. The slices contained abundant amyloid plaque, tau, and $\alpha$ Syn pathology. Antibody A recognized NFTs in the patient brain, but not in the control brain (Fig. 3A). The same antibody also bound Lewy bodies in patient brain, but not in control brain (Fig. 3B). NFTs were also detected with Antibody B-I (Fig. 3C) and antibody B-II (Fig. 3D). Although C1q was reported to be detectable around Thioflavin-positive plaques [29], we could not obtain a specific signal using this assay that could be reliably interpreted (results not shown).

\section{Inhibition of de novo aggregation of tau}

Since tau is the common target of all three bispecific antibodies, we focused most of our analysis on functional assays related to tau pathology. We used a modified version of a previously established cellfree aggregation assay (Fig. 4A). Similar assays were previously used to test the ability of tau antibodies to inhibit aggregation [56-59]. Antibodies were coincubated with tau protein (2N4R) and heparin was subsequently added to start the aggregation process. $\beta$-sheet binding dye thioflavin- $T$ was used to estimate the presence of aggregates. Indeed, we observed robust aggregation without anti-tau antibodies, which was absent when tau was omitted (Fig. 4B). The mean values of these conditions were used to determine $0 \%$ and $100 \%$ aggregation for normalization. The nonnormalized fluorescent signal also shows the effect of the antibodies on tau aggregation kinetics over time (Fig. 4C).

Antibody $\mathrm{A}_{\text {mono-tau, which binds to the distal ami- }}$ no-terminus of tau, reduced aggregation of recombinant tau to a mean value of $73.3 \%$ (corrected $p \leq 0.001,95 \%$ confidence intervals 64.7-81.8). Its bispecific counterpart, Antibody A, reduced aggregation to $41.2 \%$ (corrected $p \leq 0.001$, CI 34.2-48.1). Surprisingly, bispecific Antibody A was more effective at reducing aggregation compared to its monospecific counterpart (corrected $p \leq 0.001$ ) (Fig. 4B). These results indicate that for bispecific antibodies in this format targeting the amino-terminus, it may be more efficacious to have anti-tau scFvs rather than anti-tau $\mathrm{IgG}$ in this assay. 
A
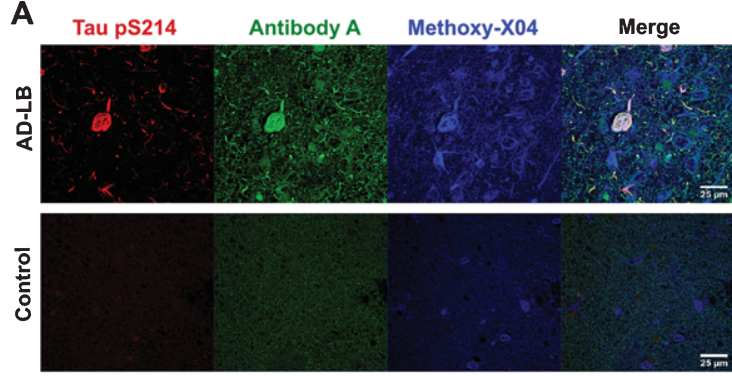

C
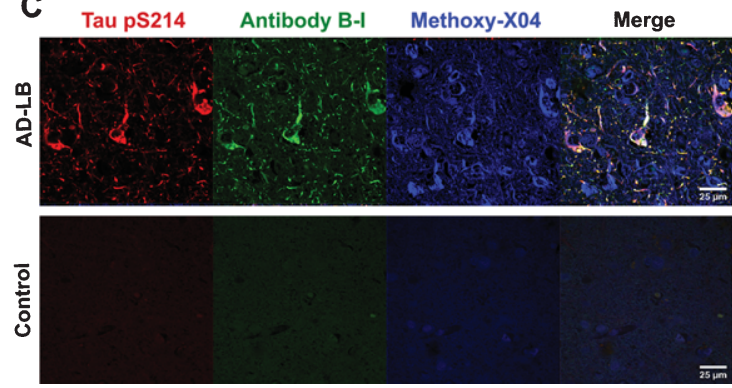

B
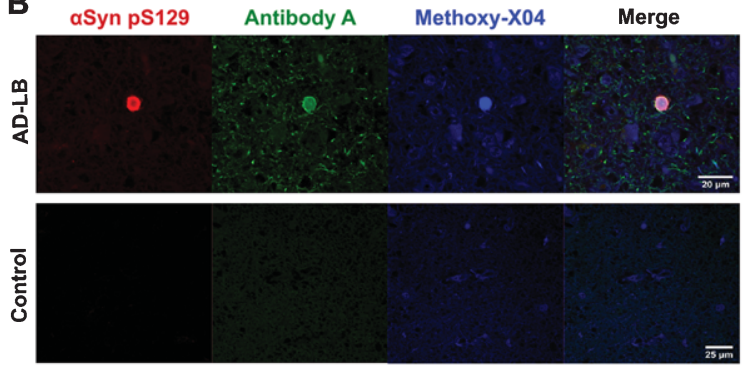

D Tau pS214 Antibody B-II Methoxy-X04 Merge

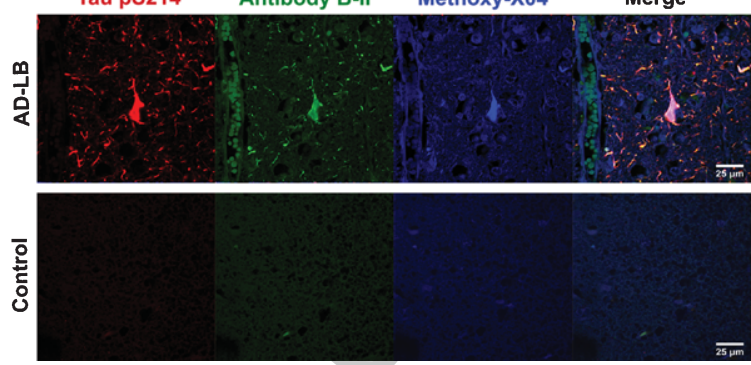

Fig. 3. Histological detection of neurofibrillary tangles (NFTs) and Lewy bodies in patient brain sections. Bispecific antibodies were tested for their ability to recognize proteinopathy in an AD patient with Lewy bodies. Slides were co-labelled with $\beta$-sheet-specific dye Methoxy-04 and tau pS214 or $\alpha$ Syn pS129. A) Antibody A recognized pS214 and Methoxy-X04 positive NFTs in patient tissue. Signal was absent in control. B) Antibody A recognized pS129 and Methoxy-X04 positive Lewy bodies in patient tissue. Signal was absent in control. C) Antibody B-I recognized pS214 and Methoxy-X04 positive NFTs in patient tissue. Signal was absent in control. D) Antibody B-II recognized pS214 and Methoxy-X04 positive NFTs in patient tissue. Signal was absent in control.

To test the influence of the bispecific antibody format further, we tested both antibody B-I and BII and their monospecific counterpart in the same assay (Fig. 4B). The bispecific antibodies behave similar to one another, except that their $\mathrm{IgG}$ and $\mathrm{scFv}$ binding sites are in opposite configuration. The binding regions of monospecific antibody B and the bispecific counterparts recognize a central epitope on tau (amino acids 235-246) [44]. Antibody B Bono-tau inhibited tau aggregation to only $6.9 \%$ (corrected $p \leq 0.001$, CI 2.6-11.2). Bispecific antibody B-I inhibited tau aggregation to $2.4 \%$ (corrected $p \leq 0.001$, CI 0.9-4.0). Antibody $B_{\text {mono-tau }}$ inhibited tau aggregation to $8.0 \%$ (corrected $p \leq 0.001$, CI 6.8-9.2). Antibody B-I was slightly more effective at inhibiting tau aggregation compared to Antibody $\mathrm{B}_{\text {mono-tau }}$ and antibody B-II (both corrected $p$-values below 0.001).

Antibody $\mathrm{B}_{\text {mono-tau }}$ was more effective than Antibody $\mathrm{A}_{\text {mono-tau }}$ despite similar affinity to tau (corrected $p \leq 0.001$ ) (Fig. 2B, Table 1), indicating that mid-domain antibodies are more effective at inhibiting recombinant tau aggregation than amino-terminus antibodies. Surprisingly, Antibody $\mathrm{B}_{\text {mono-tau }}$ was as effective at inhibiting tau aggregation as the positive control antibody 3E8-1A6 (corrected $p=$ 0.116 ), which inhibited tau aggregation to only $3.7 \%$ compared to vehicle control (corrected $p \leq 0.001$, CI 2.8-4.6). Antibody 3E8-1A6 binds to one of the two hexapeptides in the repeat domain of tau, which are supposed to be responsible for aggregation [60, 61]. This antibody was selected because antibodies targeting this domain were previously shown to potently inhibit recombinant tau aggregation in similar assays [59, 62]. Negative control antibody 2B11, which only recognizes tau phosphorylated at threonine 231 (absent on recombinant tau), did not reduce tau aggregation (Fig. 4B)

\section{Inhibition of cellular seeding induced by pathological tau from $A D$ brain}

Cellular uptake of pathological tau from the extracellular space can lead to seeded aggregation of physiological tau in vitro. This process can be blocked by pre-incubation of pathological tau with antibodies and similar assays have been used previously to identify efficacious tau antibodies [34, 44, 63-65]. We developed a similar assay to test if the bispecific antibodies retained their ability to inhibit seeded aggregation induced by AD-derived sarkosylinsoluble tau (Fig. 4C). Seeding was detected using a sensitive FRET assay as previously described [44]. 
A

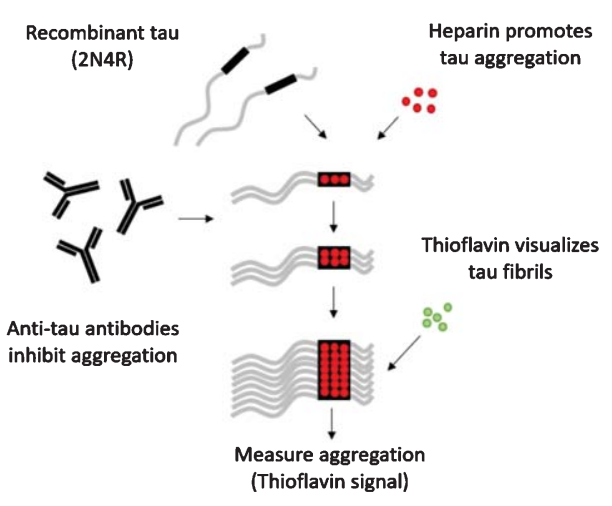

C

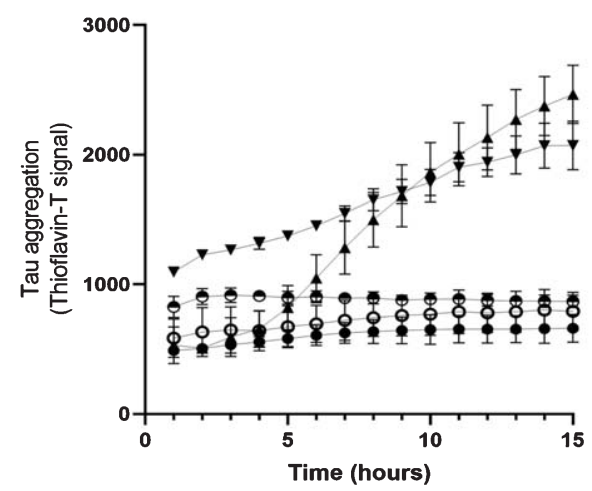

D

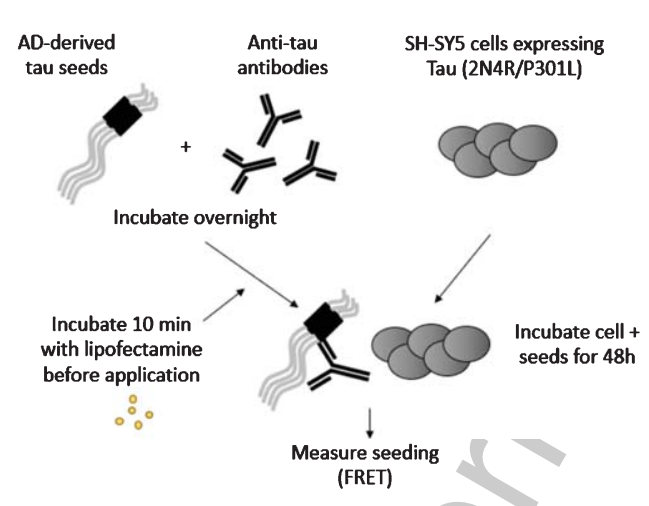

B

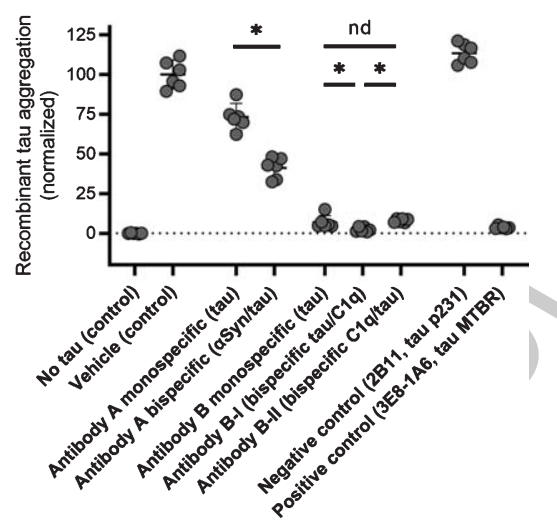

- Antibody A monospecific (tau)

- Antibody A bispecific (aSyn/tau)

- Antibody B monospecific (tau)

- Antibody B-I (tau/C1q)

Fig. 4. Comparison of mono-and bispecific antibodies in their ability to inhibit tau aggregation and tau seeding. A) Schematic representation of the recombinant tau-based aggregation assay. B) Comparison of antibodies in recombinant tau-based aggregation assay. Horizontal lines represent the mean and error bars represent the 95\% confidence intervals. Only comparisons between monospecific antibodies and their bispecific counterparts are highlighted here. Detailed information is described in the corresponding results section. C) Effect of Antibody A and Antibody B and their bispecific counterparts on tau aggregation kinetics over time. D) Schematic representation of the AD tau-based cellular seeding assay. E) Comparison of antibodies in recombinant tau-based cellular seeding assay. Horizontal lines represent the mean. No confidence intervals are shown because the data did not follow a Gaussian distribution. Only comparisons between monospecific antibodies and their bispecific counterparts are highlighted here. Detailed information is described in the corresponding results section.

After estimating the tau concentration of the insoluble fraction of our $\mathrm{AD}$ brain extract, we tested a range of doses of both AD-Tau and lipofectamine. We determined that $2.5 \mu \mathrm{g}$ AD-Tau with $1 \mu \mathrm{L}$ lipofectamine led to robust seeding without negative effects on cellviability. In a next step, we tried a range of doses of commercial anti-human tau antibody HT7, which was previously used as a positive control in similar 
assays [64-67] (not shown). Based on these results and the dosage used in previous publications [44, 64], we determined $300 \mathrm{nM}$ to be a suitable neutralizing concentration and this dose was used for further experiments. Several studies have demonstrated that complexes of tau and murine antibodies can be taken up into mouse neurons via Fc receptors [68, 69], but the results of mouse antibodies poorly translate to their chimeric counterparts with a human IgG backbone [70]. Since our antibodies are all mouse IgG1 and our cells are of human origin, we did not assess this in our study.

We next tested the bispecific antibodies and their monospecific counterparts in this assay. High variability and lack of Gaussian distribution were observed in the vehicle control condition but not in most antibody conditions, leading us to use a relatively strict non-parametric statistical test (see Methods section). Antibody $\mathrm{A}_{\text {mono-tau }}$ and Antibody $\mathrm{A}$ both bind to the amino-terminal of tau. Antibodies against this domain were previously shown to be not very effective at reducing seeding with of sarkosyl insoluble $\mathrm{AD}$ brain extract $[44,64]$. Indeed, antibody $\mathrm{A}_{\text {mono-tau }}$ did not reduce cellular seeding (correct $p=0.901$, mean value of $46.9 \%$, CI 40.6-53.2). Likewise, Antibody A also did not reduce cellular seeding (corrected $p \geq 0.999$, mean value of $73.2 \%$, CI 49.4-97.0). No difference was observed between Antibody $\mathrm{A}_{\text {mono-tau }}$ and Antibody A in this assay (corrected $p \geq 0.999$ ). In contrast, pre-incubation with Antibody $\mathrm{B}_{\text {mono-tau }}$ neutralized AD-Tau-induced seeding to $8.9 \%$ (corrected $p \leq 0.001$, CI 6.5-11.3) Antibody B-I also inhibited seeding (corrected $p \leq 0.001$, mean value of 22.3\%, CI 17.9-26.7), as did Antibody B-II (corrected $p \leq 0.001,25.4 \%$, CI 22.2-28.7) (Fig. 5B). No differences were observed between Antibody $\mathrm{B}_{\text {mono-tau }}$ and Antibody B-I (corrected $p \geq 0.999$ ) or antibody B-II (corrected $p=0.318$ ). Likewise, no differences were observed between bispecific antibodies B-I and B-II (corrected $p \geq 0.999$ ).

\section{Inhibition of classical complement}

$\mathrm{C} 1 \mathrm{q}$ is the initiating factor of the classical complement pathway, which ultimately culminates into the lysis of the cells via formation of the membrane attack complex [23]. Classical complement activation can be initiated after antibodies bind to their targets (e.g., bacteria). $\mathrm{Clq}$ then binds to the $\mathrm{Fc}$ domain of IgG molecules to trigger the classical complement cascade [71]. The level of classical complement activation can be quantified using the widely used complement hemolysis 50\% (CH50) assay [72]. In this assay, IgG-coated red blood cells are incubated with human serum, which contains all complement proteins. By making a plasma dilution curve and examining the resulting hemolysis, this assay can be used to estimate complement activity in the blood. This assay can be modified to test the neutralizing effect of $\mathrm{Clq}$ antibodies, which is accomplished by
667

668

669

670
A

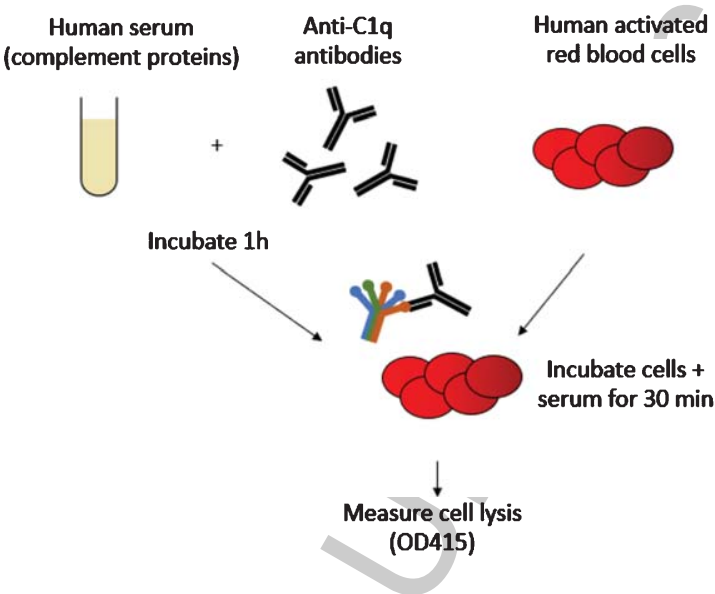

B

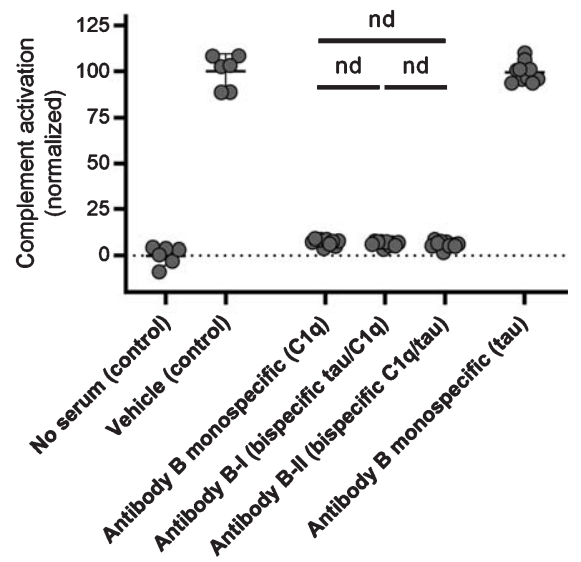

Fig. 5. Comparison of mono- and bispecific antibodies in their ability to inhibit the classical complement pathway. A) Schematic representation of the modified version of the $\mathrm{CH} 50$ assay to measure inhibition of classical complement activation. B) Comparison of antibodies in the modified CH50 assay. Horizontal lines represent the mean and error bars represent the 95\% confidence intervals. Only comparisons between monospecific antibodies and their bispecific counterparts are highlighted here. Detailed information is described in the corresponding results section. 
pre-incubation of serum with the experimental antibodies before application to the red blood cells [30] (Fig. 5A).

We used this assay to compare the complement neutralizing effects of Antibody $\mathrm{B}_{\text {mono-C1q }}$, Antibody B-I, and Antibody B-II (Fig. 5B). A condition without serum was used a negative control to estimate $0 \%$ classical complement activation. Serum without experimental IgG was used as a positive control to estimate $100 \%$ classical complement inhibition. We used a dose that was previously reported to lead to full neutralization of classical complement [30]. Indeed, Antibody $\mathrm{B}_{\text {mono-C1q }}$ inhibited classical complement activity to a mean of $7.2 \%$ (corrected $p \leq 0.0001$, CI 6.0-8.5). As expected, antibody $\mathrm{B}_{\text {mono-Tau which }}$ does not bind $\mathrm{Clq}$, was completely inactive in this assay (corrected $p=0.882$; mean value of $p=99.39$, CI 95.5-103.3). This demonstrates that the observed effect could be explained by selective neutralization of C1q. Antibody B-I potently neutralized classical complement (corrected $p \leq 0.001$, mean value of 6.4\%, CI 5.4-7.3), as did Antibody B-II (corrected $p \leq 0.001$, mean value of $5.9 \%$, CI 4.6-7.3) No differences were observed between antibody $\mathrm{B}_{\text {mono-tau }}$ and Antibody B-I (corrected $p=0.218$ ) or Antibody B-II (corrected $p=0.116$ ). Likewise, no differences were observed between Antibody B-I and Antibody B-II (corrected $p=0.546$ ).

\section{DISCUSSION}

This study describes the development and use of bispecific antibodies as a new approach to simultaneously target multiple pathological targets. For this proof-of-principle study we selected $\alpha$ Syn and C1q because tau pathology often co-occurs with Lewy body pathology as well as classical complement activation. However, this approach can in principle be extended to any desired combination of targets. The affinities of the antibodies developed here range from comparable to one order magnitude lower in comparison to their monospecific counterparts. It is possible that antibodies may deviate slightly from the originally described versions because of the different IgG backbone and bispecific format. Importantly, the bispecific antibodies retained their ability to inhibit tau aggregation, cellular tau seeding and classical complement-mediated hemolysis. This was not dependent on the location of the target binding CDRs on the antibody.
Several other interesting approaches have been described to simultaneously target multiple targets. Vaccines that in parallel target $A \beta$ plus tau [73], $\alpha$ Syn [74], or complement protein C5a [75] showed efficacy in transgenic animals. Although this is a highly promising approach, it remains to be determined to what extent vaccines are a suitable tool for treating neurodegenerative disorders. The main limitation is the lack of control over antibody titers, which may be particularly problematic in the context of aging [76]. In contrast to monoclonal antibodies, it is not clear that all antibodies raised naturally by the vaccine will have acceptable affinity and therapeutic efficacy. Furthermore, it is not possible to change the effector function of the resulting antibodies, possibly leading to undesirable and even irreversible neuroinflammation [77]. Finally, it is unclear to what extent monoclonal antibodies enter the brain parenchyma. These limitations led to the rise of engineered monoclonal antibodies with blood-brain barrier shuttles $[39,40]$, which is not possible with naturally produced antibodies in response to a vaccine. Bispecific antibodies, like the ones used in this study, can be engineered to be effector-neutral and have increased brain uptake.

Several studies described antibodies that bind to the $\beta$-sheet-rich structures, of which NPT008 is currently undergoing clinical trials [78-82]. This is a fascinating approach with the potential to simultaneously target multiple amyloidic proteins. It is, however, still an open question whether conformation-selective antibodies bind the full range of potential pathogenic states of molecules: misfolded monomers, soluble oligomers, protofibrils, and fibrils. In addition, this would only work as a combination therapy against aggregated proteins. With the advent of promising neuroinflammation-related targets for the treatment of neurodegenerative disorders, this might pose a potential limitation [23, 83]. However, since these antibodies can also be developed in bispecific formats, this opens the door to developing antibodies that can bind to multiple aggregated proteins with one binding site and neuroinflammationrelated target with another.

Recent studies also describe the functional characterization of a small molecule that can simultaneously target monomeric tau and $\alpha$ Syn or peptides that bind both tau and $A \beta[84,85]$. In addition, an oligomerspecific small molecule anle $138 \mathrm{~b}$ reduces both $\alpha$ Syn and tau aggregation in vitro and reduces both $\alpha$ Syn and tau pathology in mouse models [86-90]. The major advantage of small molecules compared to 
monoclonal antibodies is the low cost. However, in contrast to the high specificity of therapeutic monoclonal antibodies, it is unclear to what extent bispecific small molecules have low off-target binding. Furthermore, this approach is mostly likely not feasible for any combination of targets. In contrast, the modular nature of bispecific antibodies makes it easy to construct them against a wide range of target combinations.

\section{Limitations}

The main limitation of this study is that we focused only on a single bispecific antibody format. It is therefore unclear how these results translate to other multispecific antibody formats. Furthermore, Antibody B-I and B-II had approximately one order of magnitude lower affinity to tau. This suggests that further optimization of these bispecific antibodies is required to retain the affinity of the monospecific parent antibodies.

\section{CONCLUSION}

In conclusion, we present a previously uncharacterized approach to simultaneously target multiple targets involved in pathological processes in neurodegeneration. The concept of this type of bispecific antibody expands the toolkit with treatment options for neurodegenerative disorders. Importantly, when only one of the two targets is present, the bispecific antibody will function just like a regular monospecific antibody. This demonstrates that the additional binding capacity does not come at the cost of decreased overall antibody functionality compared to the original antibody. A wide range of multispecific antibody formats have been described in the literature, which may each have their unique strengths when targeting different neurodegeneration-related targets [91]. Bispecific antibodies are therefore a promising approach and could be explored against a wide range of target combinations to obtain potential synergistic effects.

\section{ACKNOWLEDGMENTS}

We would like to thank the patients and their families for their donations and the Netherlands Brain Bank for providing the material for this project.

This study was funded by Maptimmune.

Authors' disclosures available online (https:// www.j-alz.com/manuscript-disclosures/20-1334r2).

\section{REFERENCES}

[1] Hoglinger GU, Respondek G, Kovacs GG (2018) New classification of tauopathies. Rev Neurol (Paris) 174, 664-668.

[2] Vogels T, Leuzy A, Cicognola C, Ashton NJ, Smolek T, Novak M, Blennow K, Zetterberg H, Hromadka T, Zilka N, Schöll M (2020) Propagation of tau pathology: Integrating insights from postmortem and in vivo studies. Biol Psychiatry 87, 808-818.

[3] Moussaud S, Jones DR, Moussaud-Lamodiere EL, Delenclos M, Ross OA, McLean PJ (2014) Alpha-synuclein and tau: Teammates in neurodegeneration? Mol Neurodegener 9, 43.

[4] Spires-Jones TL, Attems J, Thal DR (2017) Interactions of pathological proteins in neurodegenerative diseases. Acta Neuropathol 134, 187-205

[5] Hansen L, Salmon D, Galasko D, Masliah E, Katzman R, DeTeresa R, Thal L, Pay MM, Hofstetter R, Klauber M (1990) The Lewy body variant of Alzheimer's disease: A clinical and pathologic entity. Neurology 40, 1-8.

[6] Forstl H, Burns A, Luthert P, Cairns N, Levy R (1993) The Lewy-body variant of Alzheimer's disease. Clinical and pathological findings. Br J Psychiatry 162, 385-392.

[7] Thomas AJ, Mahin-Babaei F, Saidi M, Lett D, Taylor JP, Walker L, Attems J (2018) Improving the identification of dementia with Lewy bodies in the context of an Alzheimer'stype dementia. Alzheimers Res Ther 10, 27.

[8] Roudil J, Deramecourt V, Dufournet B, Dubois B, Ceccaldi M, Duyckaerts C, Pasquier F, Lebouvier T (2018) Influence of Lewy pathology on Alzheimer's disease phenotype: A retrospective clinico-pathological study. $J$ Alzheimers Dis 63, 1317-1323.

[9] Twohig D, Nielsen HM (2019) alpha-synuclein in the pathophysiology of Alzheimer's disease. Mol Neurodegener 14, 23.

[10] Visanji NP, Lang AE, Kovacs GG (2019) Beyond the synucleinopathies: Alpha synuclein as a driving force in neurodegenerative comorbidities. Transl Neurodegener 8, 28.

[11] Karanth S, Nelson PT, Katsumata Y, Kryscio RJ, Schmitt FA, Fardo DW, Cykowski MD, Jicha GA, Van Eldik LJ, Abner EL (2020) Prevalence and clinical phenotype of quadruple misfolded proteins in older adults. JAMA Neurol 77, 1299-1307.

[12] Jellinger KA, Seppi K, Wenning GK, Poewe W (2002) Impact of coexistent Alzheimer pathology on the natural history of Parkinson's disease. J Neural Transm 109, 329339.

[13] Compta Y, Parkkinen L, O'Sullivan SS, Vandrovcova J, Holton JL, Collins C, Lashley T, Kallis C, Williams DR, de Silva R, Lees AJ, Revesz T (2011) Lewy- and Alzheimertype pathologies in Parkinson's disease dementia: Which is more important? Brain 134, 1493-1505.

[14] Irwin DJ, Grossman M, Weintraub D, Hurtig HI, Duda JE, Xie SX, Lee EB, Van Deerlin VM, Lopez OL, Kofler JK, Nelson PT, Jicha GA, Woltjer R, Quinn JF, Kaye J, Leverenz JB, Tsuang D, Longfellow K, Yearout D, Kukull W, Keene CD, Montine TJ, Zabetian CP, Trojanowski JQ (2017) Neuropathological and genetic correlates of survival and dementia onset in synucleinopathies: A retrospective analysis. Lancet Neurol 16, 55-65.

[15] Coughlin D, Xie SX, Liang M, Williams A, Peterson C, Weintraub D, McMillan CT, Wolk DA, Akhtar RS, Hurtig HI, Branch Coslett H, Hamilton RH, Siderowf AD, Duda JE, Rascovsky K, Lee EB, Lee VM-Y, Grossman M, Trojanowski JQ, Irwin DJ (2019) Cognitive and pathological 
influences of tau pathology in Lewy body disorders. Ann Neurol 85, 259-271.

[16] van der Zande JJ, Steenwijk MD, Ten Kate M, Wattjes MP, Scheltens P, Lemstra AW (2018) Gray matter atrophy in dementia with Lewy bodies with and without concomitant Alzheimer's disease pathology. Neurobiol Aging 71, 171178.

[17] Ferman TJ, Aoki N, Boeve BF, Aakre JA, Kantarci K, GraffRadford J, Parisi JE, Van Gerpen JA, Graff-Radford NR, Uitti RJ, Pedraza O, Murray ME, Wszolek ZK, Reichard RR, Fields JA, Ross OA, Knopman DS, Petersen RC, Dickson DW (2020) Subtypes of dementia with Lewy bodies are associated with alpha-synuclein and tau distribution. Neurology 95, e155-e165.

[18] Giasson BI, Forman MS, Higuchi M, Golbe LI, Graves CL, Kotzbauer PT, Trojanowski JQ, Lee VM-Y (2003) Initiation and synergistic fibrillization of tau and alpha-synuclein. Science 300, 636-640.

[19] Guo JL, Covell DJ, Daniels JP, Iba M, Stieber A, Zhang B, Riddle DM, Kwong LK, Xu Y, Trojanowski JQ, Lee VMY (2013) Distinct alpha-synuclein strains differentially promote tau inclusions in neurons. Cell 154, 103-117.

[20] Bassil F, Brown HJ, Pattabhiraman S, Iwasyk JE, Maghames CM, Meymand ES, Cox TO, Riddle DM, Zhang B, Trojanowski JQ, Lee VM-Y (2020) Amyloid-beta (Abeta) plaques promote seeding and spreading of alpha-synuclein and tau in a mouse model of Lewy body disorders with abeta pathology. Neuron 105, 260-275.

[21] Takaichi Y, Chambers JK, Inoue H, Ano Y, Takashima A, Nakayama H, Uchida K (2020) Phosphorylation and oligomerization of alpha-synuclein associated with GSK3beta activation in the rTg4510 mouse model of tauopathy. Acta Neuropathol Commun 8, 86.

[22] Uchihara T, Giasson BI (2016) Propagation of alphasynuclein pathology: Hypotheses, discoveries, and yet unresolved questions from experimental and human brain studies. Acta Neuropathol 131, 49-73.

[23] Vogels T, Murgoci A-N, Hromadka T (2019) Intersection of pathological tau and microglia at the synapse. Acta Neuropathol Commun 7, 109.

[24] Dejanovic B, Huntley MA, De Mazière A, Meilandt WJ, Wu T, Srinivasan K, Jiang Z, Gandham V, Friedman BA, Ngu H, Foreman O, Carano RAD, Chih B, Klumperman J, Bakalarski C, Hanson JE, Sheng M (2018) Changes in the synaptic proteome in tauopathy and rescue of tauinduced synapse loss by C1q antibodies. Neuron 100, 13221336.e7.

[25] Litvinchuk A, Wan Y-W, Swartzlander DB, Chen F, Cole A, Propson NE, Wang Q, Zhang B, Liu Z, Zheng H (2018) Complement $\mathrm{C} 3 \mathrm{aR}$ inactivation attenuates tau pathology and reverses an immune network deregulated in tauopathy models and Alzheimer's disease. Neuron 100, 1337-1353.

[26] Wu T, Dejanovic B, Gandham VD, Gogineni A, Edmonds R, Schauer S, Srinivasan K, Huntley MA, Wang Y, Wang T-M, Hedehus M, Barck KH, Stark M, Ngu H, Foreman O, Meilandt WJ, Elstrott J, Chang MC, Hansen D V, Carano RAD, Sheng M, Hanson JE (2019) Complement C3 is activated in human $\mathrm{AD}$ brain and is required for neurodegeneration in mouse models of amyloidosis and tauopathy. Cell Rep 28, 2111-2123.

[27] Carvalho K, Faivre E, Pietrowski MJ, Marques X, GomezMurcia V, Deleau A, Huin V, Hansen JN, Kozlov S, Danis C, Temido-Ferreira M, Coelho JE, Meriaux C, Eddarkaoui S, Gras S Le, Dumoulin M, Cellai L, Landrieu I, Chern Y, Hamdane M, Buee L, Boutillier A-L, Levi S, Halle A, Lopes
L V, Blum D (2019) Exacerbation of C1q dysregulation, synaptic loss and memory deficits in tau pathology linked to neuronal adenosine A2A receptor. Brain 142, 3636-3654.

[28] McGeer PL, Akiyama H, Itagaki S, McGeer EG (1989) Activation of the classical complement pathway in brain tissue of Alzheimer patients. Neurosci Lett 107, 341-346.

[29] Afagh A, Cummings BJ, Cribbs DH, Cotman CW, Tenner AJ (1996) Localization and cell association of C1q in Alzheimer's disease brain. Exp Neurol 138, 22-32.

[30] Hong S, Beja-Glasser VF, Nfonoyim BM, Frouin A, Li S, Ramakrishnan S, Merry KM, Shi Q, Rosenthal A, Barres BA, Lemere CA, Selkoe DJ, Stevens B (2016) Complement and microglia mediate early synapse loss in Alzheimer mouse models. Science 352, 712-716.

[31] Liddelow SA, Guttenplan KA, Clarke LE, Bennett FC, Bohlen CJ, Schirmer L, Bennett ML, Munch AE, Chung WS, Peterson TC, Wilton DK, Frouin A, Napier BA, Panicker N, Kumar M, Buckwalter MS, Rowitch DH, Dawson VL, Dawson TM, Stevens B, Barres BA (2017) Neurotoxic reactive astrocytes are induced by activated microglia. Nature 541, 481-487.

[32] Cho K (2019) Emerging roles of complement protein C1q in neurodegeneration. Aging Dis 10, 652-663.

[33] Valera E, Spencer B, Masliah E (2016) Immunotherapeutic approaches targeting amyloid-beta, alpha-synuclein, and tau for the treatment of neurodegenerative disorders. $\mathrm{Neu}$ rotherapeutics 13, 179-189.

[34] Yanamandra K, Kfoury N, Jiang H, Mahan TE, Ma S, Maloney SE, Wozniak DF, Diamond MI, Holtzman DM (2013) Anti-tau antibodies that block tau aggregate seeding in vitro markedly decrease pathology and improve cognition in vivo. Neuron 80, 402-414.

[35] Katsinelos T, Tuck BJ, Mukadam AS, McEwan WA (2019) The role of antibodies and their receptors in protection against ordered protein assembly in neurodegeneration. Front Immunol 10, 1139.

[36] Shi J-Q, Shen W, Chen J, Wang B-R, Zhong L-L, Zhu Y-W, Zhu H-Q, Zhang Q-Q, Zhang Y-D, Xu J (2011) Anti-TNFalpha reduces amyloid plaques and tau phosphorylation and induces CD11c-positive dendritic-like cell in the APP/PS1 transgenic mouse brains. Brain Res 1368, 239-247.

[37] Kitazawa M, Cheng D, Tsukamoto MR, Koike MA, Wes PD, Vasilevko V, Cribbs DH, LaFerla FM (2011) Blocking IL-1 signaling rescues cognition, attenuates tau pathology, and restores neuronal beta-catenin pathway function in an Alzheimer's disease model. J Immunol 187, 6539-6549.

[38] Scheltens P, Blennow K, Breteler MMB, de Strooper B, Frisoni GB, Salloway S, Van der Flier WM (2017) Alzheimer's disease. Lancet 388, 505-517.

[39] Kariolis MS, Wells RC, Getz JA, Kwan W, Mahon CS, Tong R, Kim DJ, Srivastava A, Bedard C, Henne KR, Giese T, Assimon VA, Chen X, Zhang Y, Solanoy H, Jenkins K, Sanchez PE, Kane L, Miyamoto T, Chew KS, Pizzo ME, Liang N, Calvert MEK, DeVos SL, Baskaran S, Hall S, Sweeney ZK, Thorne RG, Watts RJ, Dennis MS, Silverman AP, Zuchero YJY (2020) Brain delivery of therapeutic proteins using an Fc fragment blood-brain barrier transport vehicle in mice and monkeys. Sci Transl Med 12, eaay1359.

[40] Hultqvist G, Syvanen S, Fang XT, Lannfelt L, Sehlin D (2017) Bivalent brain shuttle increases antibody uptake by monovalent binding to the transferrin receptor. Theranostics 7, 308-318

[41] Labrijn AF, Janmaat ML, Reichert JM, Parren PWHI (2019) Bispecific antibodies: A mechanistic review of the pipeline. Nat Rev Drug Discov 18, 585-608. 
[42] Uemura N, Uemura MT, Luk KC, Lee VM-Y, Trojanowski JQ (2020) Cell-to-cell transmission of tau and $\alpha$-synuclein. Trends Mol Med 26, 936-952.

[43] Sevigny J, Chiao P, Bussiere T, Weinreb PH, Williams L, Maier M, Dunstan R, Salloway S, Chen T, Ling Y, O'Gorman J, Qian F, Arastu M, Li M, Chollate S, Brennan MS, Quintero-Monzon O, Scannevin RH, Arnold HM, Engber T, Rhodes K, Ferrero J, Hang Y, Mikulskis A, Grimm J, Hock C, Nitsch RM, Sandrock A (2016) The antibody aducanumab reduces Abeta plaques in Alzheimer's disease. Nature 537, 50-56.

[44] Courade J-P, Angers R, Mairet-Coello G, Pacico N, Tyson K, Lightwood D, Munro R, McMillan D, Griffin R, Baker T, Starkie D, Nan R, Westwood M, Mushikiwabo M-L, Jung S, Odede G, Sweeney B, Popplewell A, Burgess G, Downey P, Citron M (2018) Epitope determines efficacy of therapeutic anti-tau antibodies in a functional assay with human Alzheimer Tau. Acta Neuropathol 136, 729-745.

[45] Masliah E, Rockenstein E, Mante M, Crews L, Spencer B, Adame A, Patrick C, Trejo M, Ubhi K, Rohn TT, Mueller-Steiner S, Seubert P, Barbour R, McConlogue L, Buttini M, Games D, Schenk D (2011) Passive immunization reduces behavioral and neuropathological deficits in an alpha-synuclein transgenic model of Lewy body disease. PLoS One 6, e19338.

[46] Baudino L, Shinohara Y, Nimmerjahn F, Furukawa J, Nakata M, Martínez-Soria E, Petry F, Ravetch J V, Nishimura S, Izui S (2008) Crucial role of aspartic acid at position 265 in the $\mathrm{CH} 2$ domain for murine $\operatorname{IgG} 2 \mathrm{a}$ and $\operatorname{IgG} 2 \mathrm{~b}$ Fc-associated effector functions. I Immunol 181, 66646669.

[47] Azatian SB, Kaur N, Latham MP (2019) Increasing the buffering capacity of minimal media leads to higher protein yield. J Biomol NMR 73, 11-17.

[48] Mikolajczyk J, Drag M, Bekes M, Cao JT, Ronai Z, Salvesen GS (2007) Small ubiquitin-related modifier (SUMO)specific proteases: Profiling the specificities and activities of human SENPs. J Biol Chem 282, 26217-26224.

[49] Jakes R, Spillantini MG, Goedert M (1994) Identification of two distinct synucleins from human brain. FEBS Lett $\mathbf{3 4 5}$, 27-32.

[50] Kang L, Moriarty GM, Woods LA, Ashcroft AE, Radford SE, Baum J (2012) N-terminal acetylation of $\alpha$-synuclein induces increased transient helical propensity and decreased aggregation rates in the intrinsically disordered monomer. Protein Sci 21, 911-917.

[51] Horvath I, Blockhuys S, Sulskis D, Holgersson S, Kumar R, Burmann BM, Wittung-Stafshede P (2019) Interaction between copper chaperone Atox1 and Parkinson's disease protein alpha-synuclein includes metal-binding sites and occurs in living cells. ACS Chem Neurosci 10, 46594668.

[52] Burmann BM, Gerez JA, Matecko-Burmann I, Campioni S, Kumari P, Ghosh D, Mazur A, Aspholm EE, Sulskis D, Wawrzyniuk M, Bock T, Schmidt A, Rudiger SGD, Riek R, Hiller S (2020) Regulation of alpha-synuclein by chaperones in mammalian cells. Nature 577, 127-132.

[53] Vogels T, Vargová G, Brezováková V, Quint WH, Hromádka $\mathrm{T}$ (2020) Viral delivery of non-mutated human truncated tau to neurons recapitulates key features of human tauopathy in wild-type mice. J Alzheimers Dis 77, 551-568.

[54] Eckermann K, Mocanu M-M, Khlistunova I, Biernat J, Nissen A, Hofmann A, Schonig K, Bujard H, Haemisch A, Mandelkow E, Zhou L, Rune G, Mandelkow E-M (2007) The beta-propensity of tau determines aggregation and synaptic loss in inducible mouse models of tauopathy. $J$ Biol Chem 282, 31755-31765.

[55] Klunk WE, Bacskai BJ, Mathis CA, Kajdasz ST, McLellan ME, Frosch MP, Debnath ML, Holt DP, Wang Y, Hyman BT (2002) Imaging Abeta plaques in living transgenic mice with multiphoton microscopy and methoxy-X04, a systemically administered Congo red derivative. J Neuropathol Exp Neurol 61, 797-805.

[56] van Ameijde J, Crespo R, Janson R, Juraszek J, Siregar B, Verveen H, Sprengers I, Nahar T, Hoozemans JJ, Steinbacher S, Willems R, Delbroek L, Borgers M, Dockx K, Van Kolen K, Mercken M, Pascual G, Koudstaal W, Apetri A (2018) Enhancement of therapeutic potential of a naturally occurring human antibody targeting a phosphorylated Ser(422) containing epitope on pathological tau. Acta Neuropathol Commun 6, 59.

[57] Apetri A, Crespo R, Juraszek J, Pascual G, Janson R, Zhu X, Zhang H, Keogh E, Holland T, Wadia J, Verveen H, Siregar $\mathrm{B}$, Mrosek M, Taggenbrock R, Ameijde J, Inganas H, van Winsen M, Koldijk MH, Zuijdgeest D, Borgers M, Dockx K, Stoop EJM, Yu W, Brinkman-van der Linden EC, Ummenthum K, van Kolen K, Mercken M, Steinbacher S, de Marco D, Hoozemans JJ, Wilson IA, Koudstaal W, Goudsmit J (2018) A common antigenic motif recognized by naturally occurring human VH5-51/VL4-1 anti-tau antibodies with distinct functionalities. Acta Neuropathol Commun 6, 43.

[58] Crespo R, Koudstaal W, Apetri A (2018) In vitro assay for studying the aggregation of tau protein and drug screening. $J$ Vis Exp 141, doi: $10.3791 / 58570$

[59] Kontsekova E, Zilka N, Kovacech B, Skrabana R, Novak M (2014) Identification of structural determinants on tau protein essential for its pathological function: Novel therapeutic target for tau immunotherapy in Alzheimer's disease. Alzheimers Res Ther 6, 45.

[60] von Bergen M, Friedhoff P, Biernat J, Heberle J, Mandelkow EM, Mandelkow E (2000) Assembly of tau protein into Alzheimer paired helical filaments depends on a local sequence motif ((306)VQIVYK(311)) forming beta structure. Proc Natl Acad Sci U S A 97, 5129-5134.

[61] von Bergen M, Barghorn S, Li L, Marx A, Biernat J, Mandelkow EM, Mandelkow E (2001) Mutations of tau protein in frontotemporal dementia promote aggregation of paired helical filaments by enhancing local beta-structure. J Biol Chem 276, 48165-48174.

[62] Roberts M, Sevastou I, Imaizumi Y, Mistry K, Talma S, Dey M, Gartlon J, Ochiai H, Zhou Z, Akasofu S, Tokuhara N, Ogo M, Aoyama M, Aoyagi H, Strand K, Sajedi E, Agarwala KL, Spidel J, Albone E, Horie K, Staddon JM, de Silva R (2020) Pre-clinical characterisation of E2814, a highaffinity antibody targeting the microtubule-binding repeat domain of tau for passive immunotherapy in Alzheimer's disease. Acta Neuropathol Commun 8, 13.

[63] Pascual G, Wadia JS, Zhu X, Keogh E, Kukrer B, van Ameijde J, Inganas H, Siregar B, Perdok G, Diefenbach O, Nahar T, Sprengers I, Koldijk MH, der Linden ECB, Peferoen LA, Zhang H, Yu W, Li X, Wagner M, Moreno V, Kim J, Costa M, West K, Fulton Z, Chammas L, Luckashenak N, Fletcher L, Holland T, Arnold C, Anthony Williamson R, Hoozemans JJ, Apetri A, Bard F, Wilson IA, Koudstaal W, Goudsmit J (2017) Immunological memory to hyperphosphorylated tau in asymptomatic individuals. Acta Neuropathol 133, 767-783.

[64] Vandermeeren M, Borgers M, Van Kolen K, Theunis C, Vasconcelos B, Bottelbergs A, Wintmolders C, Daneels G, Willems R, Dockx K, Delbroek L, Marreiro A, Ver Donck L, 
Sousa C, Nanjunda R, Lacy E, Van De Casteele T, Van Dam D, De Deyn PP, Kemp JA, Malia TJ, Mercken MH (2018) Anti-tau monoclonal antibodies derived from soluble and filamentous tau show diverse functional properties in vitro and in vivo. J Alzheimers Dis 65, 265-281.

[65] Nobuhara CK, DeVos SL, Commins C, Wegmann S, Moore BD, Roe AD, Costantino I, Frosch MP, Pitstick R, Carlson GA, Hock C, Nitsch RM, Montrasio F, Grimm J, Cheung AE, Dunah AW, Wittmann M, Bussiere T, Weinreb PH, Hyman BT, Takeda S (2017) Tau antibody-targeting pathological species block neuronal uptake and interneuron propagation of tau in vitro. Am J Pathol 187, 1399-1412.

[66] Takeda S, Wegmann S, Cho H, DeVos SL, Commins C, Roe AD, Nicholls SB, Carlson GA, Pitstick R, Nobuhara CK, Costantino I, Frosch MP, Muller DJ, Irimia D, Hyman BT (2015) Neuronal uptake and propagation of a rare phosphorylated high-molecular-weight tau derived from Alzheimer's disease brain. Nat Commun 6, 8490.

[67] Nicholls SB, DeVos SL, Commins C, Nobuhara C, Bennett RE, Corjuc DL, Maury E, Eftekharzadeh B, Akingbade O, Fan Z, Roe AD, Takeda S, Wegmann S, Hyman BT (2017) Characterization of TauC3 antibody and demonstration of its potential to block tau propagation. PLoS One 12, e0177914.

[68] Congdon EE, Gu J, Sait HBR, Sigurdsson EM (2013) Antibody uptake into neurons occurs primarily via clathrin-dependent Fcgamma receptor endocytosis and is a prerequisite for acute tau protein clearance. $\mathrm{J}$ Biol Chem 288, 35452-35465.

[69] Kondo A, Shahpasand K, Mannix R, Qiu J, Moncaster J, Chen C-H, Yao Y, Lin Y-M, Driver JA, Sun Y, Wei S, Luo M-L, Albayram O, Huang P, Rotenberg A, Ryo A, Goldstein LE, Pascual-Leone A, McKee AC, Meehan W, Zhou XZ, Lu KP (2015) Antibody against early driver of neurodegeneration cis P-tau blocks brain injury and tauopathy. Nature 523, 431-436.

[70] Congdon EE, Chukwu JE, Shamir DB, Deng J, Ujla D, Sait HBR, Neubert TA, Kong X-P, Sigurdsson EM (2019) Tau antibody chimerization alters its charge and binding, thereby reducing its cellular uptake and efficacy. EBioMedicine $\mathbf{4 2}$, 157-173.

[71] Veerhuis R, Nielsen HM, Tenner AJ (2011) Complement in the brain. Mol Immunol 48, 1592-1603.

[72] Prohaszka Z, Kirschfink M, Frazer-Abel A (2018) Complement analysis in the era of targeted therapeutics. $\mathrm{Mol}$ Immunol 102, 84-88.

[73] Davtyan H, Zagorski K, Rajapaksha H, Hovakimyan A, Davtyan A, Petrushina I, Kazarian K, Cribbs DH, Petrovsky N, Agadjanyan MG, Ghochikyan A (2016) Alzheimer's disease $\operatorname{Advax}(\mathrm{CpG})$ - adjuvanted MultiTEP-based dual and single vaccines induce high-titer antibodies against various forms of tau and Abeta pathological molecules. Sci Rep 6 , 28912.

[74] Mandler M, Rockenstein E, Overk C, Mante M, Florio J, Adame A, Kim C, Santic R, Schneeberger A, Mattner F, Schmidhuber S, Galabova G, Spencer B, Masliah E, Rissman RA (2019) Effects of single and combined immunotherapy approach targeting amyloid beta protein and alpha-synuclein in a dementia with Lewy bodies-like model. Alzheimers Dement 15, 1133-1148.

[75] Landlinger C, Mihailovska E, Mandler M, Galabova G, Staffler G (2017) Combinatorial vaccine against complement factor C5a and amyloid beta: A new therapeutic approach in Alzheimers disease. J Clin Cell Immunol 8, 1 .
[76] Marciani DJ (2015) Alzheimer's disease vaccine development: A new strategy focusing on immune modulation. $J$ Neuroimmunol 287, 54-63.

[77] Lee S-H, Le Pichon CE, Adolfsson O, Gafner V, Pihlgren M, Lin H, Solanoy H, Brendza R, Ngu H, Foreman O, Chan R, Ernst JA, DiCara D, Hotzel I, Srinivasan K, Hansen D V, Atwal J, Lu Y, Bumbaca D, Pfeifer A, Watts RJ, Muhs A, Scearce-Levie K, Ayalon G (2016) Antibody-mediated targeting of tau in vivo does not require effector function and microglial engagement. Cell Rep 16, 1690-1700.

[78] Levenson JM, Schroeter S, Carroll JC, Cullen V, Asp E, Proschitsky M, Chung CH-Y, Gilead S, Nadeem M, Dodiya HB, Shoaga S, Mufson EJ, Tsubery H, Krishnan R, Wright J, Solomon B, Fisher R, Gannon KS (2016) NPT088 reduces both amyloid-beta and tau pathologies in transgenic mice. Alzheimers Dement (N Y) 2, 141-155.

[79] Goni F, Marta-Ariza M, Herline K, Peyser D, Boutajangout A, Mehta P, Drummond E, Prelli F, Wisniewski T (2018) Anti-beta-sheet conformation monoclonal antibody reduces tau and Abeta oligomer pathology in an Alzheimer's disease model. Alzheimers Res Ther 10, 10.

[80] Herline K, Prelli F, Mehta P, MacMurray C, Goni F, Wisniewski T (2018) Immunotherapy to improve cognition and reduce pathological species in an Alzheimer's disease mouse model. Alzheimers Res Ther 10, 54.

[81] Goñi F, Martá-Ariza M, Peyser D, Herline K, Wisniewski $\mathrm{T}$ (2017) Production of monoclonal antibodies to pathologic $\beta$-sheet oligomeric conformers in neurodegenerative diseases. Sci Rep 7, 9881.

[82] Michelson D, Grundman M, Magnuson K, Fisher R, Levenson JM, Aisen P, Marek K, Gray M, Hefti F (2019) Randomized, Placebo Controlled Trial of NPT088, A phage-derived, amyloid-targeted treatment for Alzheimer's disease. J Prev Alzheimers Dis 6, 228-231.

[83] Francistiová L, Bianchi C, Di Lauro C, Sebastián-Serrano Á, de Diego-García L, Kobolák J, Dinnyés A, Díaz-Hernández M (2020) The role of P2X7 receptor in Alzheimer's disease. Front Mol Neurosci 13, 94.

[84] Gabr MT, Peccati F (2020) Dual Targeting of Monomeric tau and alpha-synuclein aggregation: A new multitarget therapeutic strategy for neurodegeneration. ACS Chem Neurosci 11, 2051-2057.

[85] Griner SL, Seidler P, Bowler J, Murray KA, Yang TP, Sahay S, Sawaya MR, Cascio D, Rodriguez JA, Philipp S, Sosna J, Glabe CG, Gonen T, Eisenberg DS (2019) Structure-based inhibitors of amyloid beta core suggest a common interface with tau. Elife 8, e46924.

[86] Dominguez-Meijide A, Vasili E, König A, Cima-Omori M-S, Ibáñez de Opakua A, Leonov A, Ryazanov S, Zweckstetter M, Griesinger C, Outeiro TF (2020) Effects of pharmacological modulators of $\alpha$-synuclein and tau aggregation and internalization. Sci Rep 10, 12827.

[87] Wagner J, Ryazanov S, Leonov A, Levin J, Shi S, Schmidt F, Prix C, Pan-Montojo F, Bertsch U, MittereggerKretzschmar G, Geissen M, Eiden M, Leidel F, Hirschberger T, Deeg AA, Krauth JJ, Zinth W, Tavan P, Pilger J, Zweckstetter M, Frank T, Bähr M, Weishaupt JH, Uhr M, Urlaub H, Teichmann U, Samwer M, Bötzel K, Groschup M, Kretzschmar H, Griesinger C, Giese A (2013) Anle138b: A novel oligomer modulator for disease-modifying therapy of neurodegenerative diseases such as prion and Parkinson's disease. Acta Neuropathol 125, 795-813.

[88] Levin J, Schmidt F, Boehm C, Prix C, Bötzel K, Ryazanov S, Leonov A, Griesinger C, Giese A (2014) The oligomer modulator anle $138 \mathrm{~b}$ inhibits disease progression in a 
Parkinson mouse model even with treatment started after disease onset. Acta Neuropathol 127, 779-780.

[89] Wagner J, Krauss S, Shi S, Ryazanov S, Steffen J, Miklitz C, Leonov A, Kleinknecht A, Göricke B, Weishaupt JH, Weckbecker D, Reiner AM, Zinth W, Levin J, Ehninger D, Remy S, Kretzschmar HA, Griesinger C, Giese A, Fuhrmann M (2015) Reducing tau aggregates with anle 138 b delays disease progression in a mouse model of tauopathies. Acta Neuropathol 130, 619-631.

[90] Brendel M, Deussing M, Blume T, Kaiser L, Probst F, Overhoff F, Peters F, von Ungern-Sternberg B, Ryazanov S,
Leonov A, Griesinger C, Zwergal A, Levin J, Bartenstein P, Yakushev I, Cumming P, Boening G, Ziegler S, Herms J, Giese A, Rominger A (2019) Late-stage Anle138b treatment ameliorates tau pathology and metabolic decline in a mouse model of human Alzheimer's disease tau. Alzheimers Res Ther 11, 67.

[91] Wu X, Demarest SJ (2019) Building blocks for bispecific and trispecific antibodies. Methods 154, 3-9. 